\title{
Family Business Sustainability through Community Orientation
}

\author{
Filda Rahmiati \\ Faculty of Business, President University, Bekasi, Indonesia \\ kunthi.kusumawardani@president.ac.id*
}

\begin{abstract}
This research aims to explore the sustainability of the family business through the implementation of Corporate Social Responsibility (CSR) to the community surrounding the company. As many research studies mentioned that family businesses are often strongly anchored in the local community, the high commitment to the local community will lead to a high degree of socially responsible actions. The qualitative method is used in the form of a case of an Indonesian small business in Bogor. The data collection is done using direct methods like observation, interview, and going through the company documentations to comprehend the case situation. The result of the research shows that the CSR implementation, in the case observed, was following the needs of the surrounding community. The CSR activities were in the form of education, religious activities, public facilities, employee, and community empowerment. The community and the company were supporting each other to make the activity successful. This study concludes that this symbiotic CSR could be a new model for family business enterprise's sustainability through CSR.
\end{abstract}

Keywords: Corporate Social Responsibility, Family Business, Sustainability, Education, Religious Activities, Community Empowerment.

\section{Introduction}

Contribution of family businesses greatly impacted the local and national economy and welfare as well as social sustainability (Aditya, 2011; Bakoğlu and Y1ldırım, 2016; Ernst and Young, 2014; Kumar and Prameswari, 2018). Most forms of the family business are located in Asia and continental Europe (Campopiano, 2012). Further, Mandl (2008) indicated that about $70 \%$ - $80 \%$ across Europe comprises family businesses accounted for about $40 \%-50 \%$ of employment. Most family business objectives focus on sustainability in the long term than aiming for profits. The existence of a company cannot be separated from its surroundings. Therefore, the company should realize that it cannot be focusing mainly on getting profit on its operation; hence, should company also consider the welfare of their surrounding communities (Prayudi, 2012). Aditya (2011) mentioned that companies and communities should create a good relationship, which is symbiotic mutualism.

According to Prayudi (2012), every company should fulfil three aspects of its operations; there are social, economy, and environment, which are commonly known as the triple bottom line concept. This concept should also emphasize the company's responsibility of its stakeholders, not only shareholders' interest. Indonesia, in general, focusing on the stakeholders can be referring to the triple 
bottom line concept, which focuses on Corporate Social Responsibility (CSR). The goal of CSR is to enhance the role of the company in the community. The company, therefore, could be able to survive without support for the community. CSR is the implementation of the company to stay close to the community (Setyaningrum, 2011). CSR can impact the community surroundings whereby every program run by the company should have positive impacts on the community, directly and indirectly, can improve the company's existence (Mentari, 2013).

CSR is becoming a debatable issue (Yulita, 2018). Such as the practice of CSR sometimes has not been based on the needs of the community, instead, for the company's purposes to gain the reputation and image of the company without the motive of serving the community's needs. In this study, researchers try to explore the contribution of the company, in this case of an Indonesian small business in Bogor, on how it applies the CSR to the community surrounding.

\subsection{Case Issues}

A case study of this paper is an Indonesian small business in Bogor established since 2001. It is located in Bogor City. This company has various business products such as car dealer for selling and buys new also second-hand cars, catering services, wedding equipment rentals, general contractor's project, contractor's consultancy, and selling steels. This company is a family business owned by the father as the main commissioner and the mother as the commissioner on the board. The son and daughter are positioned as directors. Along the existence of this company, currently, the company has already taken over by the second generation. The company categorizes as a small business with total employees of 25 employees. Majorities of its employees are the people surrounding the company's location, which expect to help in improving community empowerment. Also, most of the customers are from community surroundings. That is the reason that this company can sustain until today.

In light of the discussion above regarding the community-oriented CSR, this study will analyse the implementation of community-oriented CSR implemented by the company. The case questions are the following:

1. How is the contribution of the company to the community as CSR implementations?

2. What are the activities of community-oriented CSR implementation implemented by the company?

3. Is this model where there is a symbiotic relationship between the company and the community replicable?

4. Does this community-oriented CSR lead to the sustainability of the business?

\section{Literature Review}

\subsection{Family Business}

The growth of family business in Indonesia started from a close-circle family or immediate family (The Jakarta Consulting Group, 2014). Based on the Jakarta Consulting Group research found that most of the respondents mentioned that at first, the company only started by a single fighter later, they bring along their spouse. Further, this study found that in developed countries, most founders of 
family businesses did not want their descendants to work in the company. However, in Indonesia, most family businesses prefer their children to take over the business as the level of unemployment keeps on rising, creates difficulty in finding a job. Further, Safi' mentioned that family businesses have a commitment and motivation to help family members in running a business well. These acts could positively impact the spirit and skill of the family members. It can be seen that family relations in eastern countries stronger than in western countries.

Based on Bakoğlu and Yıldırım (2016) and Dobson and Swift (2008), family business define as one of three distinct types:

1. A business owned by members of the family, in which the family owns half of the shares.

2. Business is controlled by members of the family, but the family is not the majority owner.

3. A business that ownership and/or management pass from one generation to the next.

KPMG and Family Business Australia (2013) stated that characteristics of a family business in achieving their goals include providing personal challenges and rewards, family independence, and improving the family social status in the community. However, they were less satisfied with the extent to which other family-oriented goals have been achieved, such as spent time with the family, increasing family capacity, and quality of work-life balance. Family members work longer hours than non-family members as their commitment and investment in the business to see it succeed. As a result, this study found that Eighty-three percent of respondents believe that being a family business made a difference in dealing with ongoing economic uncertainty, being able to adapt and survive to market conditions, and to provide excellent services and products consistently and effectively to the customer.

Research done by Cho, Okuboyejo, and Dickson (2017) shows that many of the family business initiators do not realize the sustainability of their business to hand over the business to their successors. Nevertheless, sustainability is possible for a successful family business, but the essence of family business usually very problematic when managing the business at the same time being part of the family. There are two family business models: Three-Circle Family Business Model and Multi-Level Family Business Choice Model. The Three-Circle Family Business Model facilitates the consideration of interactions that occur in a family-owned business, which are family, business, and ownership. Long-term success depends on the functioning and mutual support in interactions. The second model is a MultiLevel Family Business Choice Model, which is about decision making in the family business objectively analyse current family and business status, interpreting their family and business mission, and understanding the outcome of these decisions, the right decisions will be made that will help the business continuity even when the initiator dies. There are problems in gaining sustainable business, such as lack of children's interests and involvement in their parent's businesses and lack of updates of employees through training programs. Also, family business owners are not often willing to incorporate non-family shareholders and hence mostly operate with little capital, which hard for them to be able to company in the industry. 
Auletta, DeWitt, Parada, Sharma, and Yusof (2014) pointed out that family businesses also need to consider the influence of non-family members. Three influences need to be considered. First is the influence of religion, family values, and social values on the way we do business. Second, technological change requires adaptation of the family business. Finally, business conditions influence their entrepreneurial efforts to adapt to political risk, market size in the global economy, or regulatory risk, so the choice of a family business is not only determined by experts in the family.

Thus, family businesses have a strong and extensive presence in today's social and economic history. A family is an old and oldest unit of society in our world (Bakoğlu and Yıldırım, 2016). In addition, Campopiano (2012) studies on Corporate Social Responsibility (CSR) and Family Business indicate that family business contribute more to CSR programs because family companies are more concerned with fostering social responsibility, think about the reputation and good visibility of their company among their closest stakeholders. Because doing things like this can lead to achieving competitive advantage to achieve their long-term goals continuity. However, a family business proved to implement CSR less according to CSR standards than their non-family business because they are less dependent on the institutional context. Thus, in this study, researchers try to explore the CSR on the family business scope.

\subsection{Corporate Social Responsibility (CSR)}

The idea of CSR has started from the 1970s until now, still in emerging issues. In Indonesia, beginning in the $1990 \mathrm{~s}$, but the growth still needs to be widely introduced by the government, community, and businesses (Setyaningrum, 2011). CSR in Indonesia arranged by Law: UU No.40 Year 2007 about Company Limited Liability. Article 74 paragraph (1) mentioned that a company that carries out its business activities in the field and/or related to natural resources is obliged to carry out social and environmental responsibility. Through this law, the industry or corporation is obligated to implement it. The development of a country is not only the responsibility of government and industry alone, but every human being plays a role in realizing social welfare and management of the quality of life of the community (Handjaja, 2013). Further, the International Organization for Standarization (2010) about ISO 26000 defines CSR as an organization's responsibility impacts on decisions and activities on society and the environment, through transparent and ethical behavior. In ISO 26000, CSR covers seven key issues, namely: community development, consumer; the practice of healthy institutional activities; the environment; employment; human rights; and governance organizations.

One definition that provides a way to think about CSR was provided by the World Business Council of Sustainable Development (1998) as a continuing commitment by business to contribute to economic development while improving the quality of life of the workforce and their families as well as of the community and society at large. Additionally, other researchers define CSR as a form of activity to improve the quality of life of the community through the enhancement of human capabilities as individuals to adapt to existing social conditions, utilize and maintain the existing environment (Setyaningrum, 2011) towards the betterment of society (Uhlaner, Goor-Balk, and Masurel, 2004) through sustainable development (Aditya (2011). 
The scope of CSR covers issues related to the environment, business ethics, community development investment, work environment, good corporate governance, human rights, and the products (Prayudi, 2012).

CSR is a form of commitment, concern, and contribution to improving the quality of life of the community. CSR will provide positive results for the company, either directly or indirectly, in the future. In the implementation of CSR, companies will usually involve community participation in improving the welfare of the community. The community can participate in the empowerment process, cooperation in optimizing the existing resources to achieve the goals of welfare. This is because the community is an essential part of gaining appreciation in the form of improving the welfare of people's lives. In its implementation, companies will generally involve community participation, both as objects and as subjects of CSR programs. This is because the community is one of the parties who are quite influential in maintaining the existence of a company. The community gets the most impact on the company's production activities (Aditya, 2011; Setyaningrum, 2011). CSR refers to all relationships that occur between a company and all stakeholders, including customers, employees, communities, owners or investors, governments, distributors, and even competitors. The development of corporate social programs can include physical assistance, health services, community development, scholarships, among others. For a CSR program to be implemented, there are several things that need to be considered: (1) who is the target group, (2) what is the indicator of success, and (3) how to follow up. CSR is currently no longer a voluntary or committed company for the activities of the company but is mandatory or an obligation for some companies to do or apply it (Aditya, 2011). CSR is closely related to sustainable development (Aditya, 2011; Setyaningrum, 2011), so a company in carrying out its activities must base its decision not solely based on financial factors alone but also to be ethical and play a role in the creation of social investment.

Another study was done by Widowati, Surjawati, Oktoriza, and TL (2017) about Islamic Corporate Social Responsibility Disclosure (ICSRD) practices. The result of their study shows that the most serious concern was the employees' theme. Employees' theme in this study covers of nature of work, education and training, equal opportunities, employee involvement, health, and safety, working environment, employment of other special, sponsoring public health. This study will also be focusing on the CSR activities concern specifically for employees. Below are the details of activities of CSR.

\subsection{Activities of CSR}

Based on Lee et al. (2012), SMEs engage primarily in activities with a direct impact on their definitive stakeholders and other activities (i.e., external social contribution). This trend can be attributed to two reasons: SMEs' organization characteristics and governmental influence. Based on this study, the CSR activities are:

1. Quality products and/or services: activities that result in better products and/or by using new technologies to improve work processes.

2. Health and safety: having safety standards, fit, and have undergone certification and the ISO process. 
3. Employees' training/retraining opportunities: encourage employees to undergo training courses.

4. Employees' enhanced benefits include employment incentives, flexible working hours for staff with special circumstances.

5. Empowerment on employees: reduce the number of employees needs to empower them with various decision-making opportunities.

A study was done by Uhlaner et al. (2004) found that a family business acted as a relationship with a particular stakeholder. The stakeholder relationships that reflect some types of CSR behaviour are:

\section{Employees}

The company provides a small action of kindness to the people in the community.

2. Clients

The company acts as leading to loyal clients.

3. Special Relationship with Suppliers

A commitment to a longstanding relationship. The company rarely changes the supplier. Further, when a supplier has problems, the company lets them overcome difficulties in some cases, helped suppliers to overcome financial difficulties.

4. Special Relationships with Sport Clubs

Providing donations in cash, giving sponsorship provided the company's logo on the uniform and also a desire to help the community and boost the community spirit.

5. Special Relationship with Church

Company donations could be linked to the family business; such as build the church or as an active member.

6. Special relationships with the physical environment

Put family surname as the business name, which impacts the reputation of the family members. The family's conscience influences the company's business decisions.

7. Special relationships with service organizations

The family aspect of their businesses influences their relationship with various service organizations, which range from worldwide to local organizations. Support varies, including financial, in-kind, and counselling.

The result shows that the family business owner considers good relationships as advantageous for that business. Most CSR behaviour are acts of kindness as well as provide support for the community job creation and supporting the local economy. The results of this study also suggest that where causes or groups are supported, they are those closest to home and family: the sports club, church group, or other local organization.

Other researchers, Aditya (2011), on his study, the implementation of CSR are divided by employees, community, and environment. The guidance of the region covering aspects of education, social, health, economy, and religion

1. Employees, CSR activities include pensions, holiday allowances, bonuses, death benefits, health benefits. Provide facilities, such as musholla, cafeteria, sports facilities, education or seminars, maternity leave, childbirth, employee cooperatives. Provide services, such as polyclinics, insurance, legal aid, home loans. 
2. Community and environment, CSR activities are:
a. Education, in the form of development of educational facilities and scholarships.
b. Health improvement, in the form of construction of village health centre providing equipment supply, provision of medical staff, and vehicles that operate to provide services to the surrounding villages.
c. Vocational education and business development, supporting the development and training of personnel, and other drivers of economic growth. Program initiatives and funding for MSMEs and.

Another researcher, Hadi (2016) found in his study that CSR activity in a commitment of applying the principles of sharia in which to foster harmonious relationships with surrounding communities. Therefore, the company continuously allocates funds for various social programs in the form of zakat, infaq, and sadaqah.

The last research was done by Sari (2014). The CSR programs done by the company were solving the main problem that occurs in the community and enhancing the community's potential. The activities done by the company are divided into several programs:

1. Public Facilities and infrastructure: renovating bridge, reforestation, road renovation, and drainage creation.

2. Education: providing educational equipment, internship, and scholarships.

3. Religious: renovating mosque, Idhul Fitr, and Idul Adha

4. Community empowerment: job opportunity, training, a donation to the local youth organization.

5. Health: a donation to Community Health Centre (Puskesmas) and support the program held by local Community Health Centre (Puskesmas).

Activities done were one of the essential elements in the formation of sustainability. With the implementation of CSR, the company expected to get a positive image from the community, gained additional capital in terms of trust from customers as well as suppliers, build qualified human resources, facilitate risk management, and lastly, continue to be close to the community located around the company location. These activities are also supported by the community surrounding the company location. The community responded very well with evidence that supporting activities from the planning stage until the implementation stage.

Based above mentioned of CSR activities from previous researchers, this case study will explore the community-oriented CSR activities in terms of employees, public facilities, education, religion, and community activities and explore if the CSR activities can enhance the sustainability of the family business as shown in Fig 1 below: 


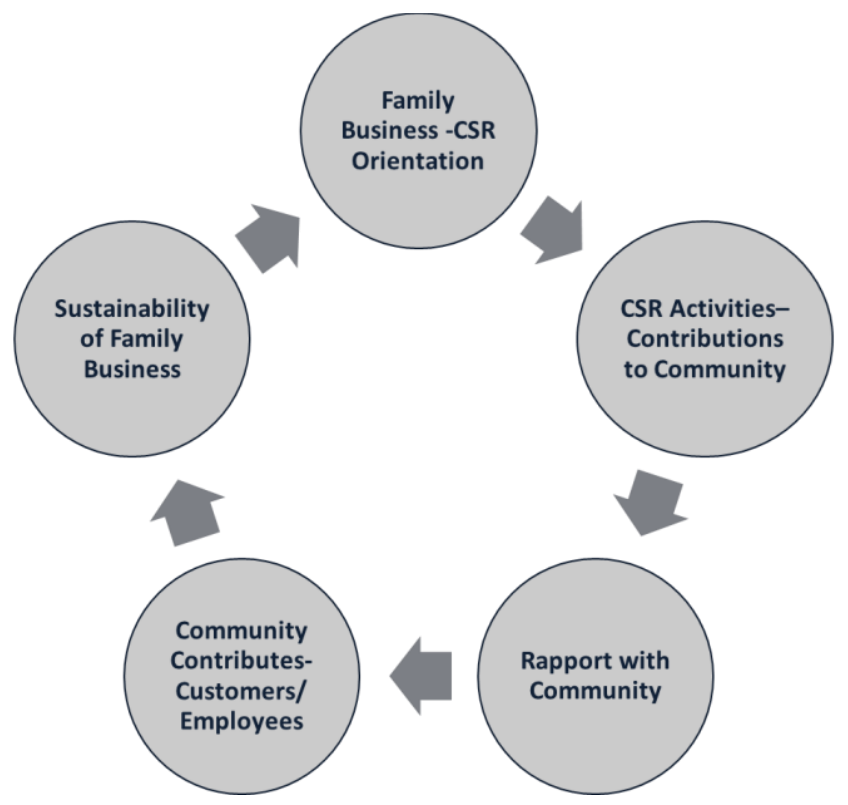

Figure 1: Sustainability Cycle for Small Family Business

\section{Research Method, Result and Discussion}

The case study uses a qualitative approach and provides evidence from the owner and employees (which the community is surrounding). The detail about the company information was already discussed in the case issue. Qualitative evidence was collected in March and April in the year 2018 via interviews and informal conversations with the owners of the company, such as the father, the mothers, and children. Further, some selected employees were also interviewed to get more information. Direct observations were done during several weeks on weekdays to see the daily business operation and also asked the owner to give some documentation as proofing of their CSR activities, which was already done. The selection of this method is based on the facts, and the focus of this research lies in the condition that occurs in the community around the company.

\section{Findings}

\subsection{Conditions in community surroundings the company}

At first, the company sees the conditions in the community before taking action on doing the CSR programs. Several considerations help the company to formulate on the CSR implementations. There are:

1. The location of the company has a community with a lack of formal education. The people surrounding are less educated. Some of them are not even finished elementary school, which hard for them to find jobs. In this case, the company realized that the human resources problem needs to be solved.

2. In the surrounding community, there are still houses with no sanitation facilities, and people do shower and wash their clothes in the river, which 
exactly beside the company location. The company sees a need to provide public facilities to accommodate the community.

3. Lack of kinder garden school in the community creates people who need to go far to send their children to school.

4. The realization that the company needs to have a religious activity to strengthen the religiosity of the employees.

5. Communities' surroundings still have some level of poverty that needs to be helped.

6. Some mosques need to be renovated to make a better place of worship.

7. Community surrounding has a music activity that lacks funding in terms of getting the music equipment.

\subsection{The contribution of the company to the community as CSR implementations}

The existence of this company is inseparable from the company's goal to empower the surrounding community. So, since the establishment of this company, CSR has been carried out by making the community surrounding as employees. Over time, other CSR activities were carried out to facilitate the surrounding community for a better life. Based on the above considerations, the company implemented several CSR activities of various social programs on community-oriented CSR activities in terms of employees, public facilities, education, religion, and community activities which the funds are from the profit of the business, also from zakat, infaq, and sadaqah, divided into:

Employees: the company absorbs the unemployed people become employees. Empower them with training to have the skill needed for their job. Further, the company provides some benefits to employees in terms of bonuses, employees' family vacation, health insurance, providing lunch, and providing loans for the need. Employ people from the community surrounding aims to reduce the unemployment level and creating productive people.

Public Facilities: constructing public sanitation to help the community in terms of getting better in health. Also, the company builds a public musholla for everyone (employees, customers, suppliers), hoping that they can do prayer during prays time while working.

Education: the company builds a kinder garden school, named Raudhatul Athfal Ar Rahmah (RA Ar Rahmah) located in Desa Laladon Gede, Kecamatan Ciomas, Kabupaten Bogor. This school, built since 2002 aimed to accommodate the surrounding communities who have kids. In the beginning, this school was occupied by some of the employees' children, later once known by the public; many students are also from outside the community. Besides building a formal education, the company is also supporting the TPA (Taman Pendidikan Al Quran) in terms of giving facilitations such as renovating a class and donating funds.

Religious: In the beginning, the owner of the company sees the need to occupied employees with the religious side. Therefore, the owner called ustad or ustadzah to come to give a religious speech. Later, communities knew it, and the audiences become larger, up to 200 audiences. The company is also donating some of its 
funds in renovating mosques in the surrounding community. During Hajj day, the company does qurban, which the meats distributed to the community. Lastly, to the distribution of zakat, the company distributes it to the mustahiq zakat in surrounding the company location.

Community activities: surrounding the company location, there is a music club "Paguyuban Sindang Barang" which plays traditional music (Sundanese music). The company donates some funds to support this activity.

Based on the results of this study, the CSR activities carried out by companies are in accordance with community needs. The model proposed in Figure 1 relates to the sustainability cycle of the small family business according to what the company does. These activities aim to increase the competitiveness of the company through a good reputation leads to a competitive advantage. The symbiotic relationship between the company and the community will have a long-term impact on the business that can create long-term business sustainability.

\section{Conclusion}

The conclusion is that the community-oriented CSR activities done by the company were in accordance with the needs of the community. This ensured that the company developed a good rapport and relationship with the surrounding community. It came out also in the interview of the employees that they came from the surrounding communities and also helped in getting customers through networking. This conclusion substantiates the model proposed in Fig 1 about the sustainability cycle of a small family business. The activities aim to create a harmonious business environment to improve the competitiveness of the company through a good reputation of the product, which aims to create a competitive advantage that is difficult to imitate by competitors. Those activities are education, religious activities, public facilities, employee, and community empowerment. As proposed by a previous study, Aditya (2011) mentioned that the company should create a good relationship that is symbiotic with the community. This case has approved that having a symbiotic relationship between the company and the community will create a long-term impact on the business itself. This result is also supported by a previous study done by (Prayudi, 2012; Sari, 2014; Setyaningrum, 2011).

By facilitating the needs of its employees, hope that they can work well, loyal, and be productive, which can improve their family's quality of life. In terms of community, support from the company hopes to create a good condition in business operation, be a loyal customer, and support the continuity of the business. Lastly, supporting the facilities and needs of the community is expected to increase the quality of life of the community surroundings. All of the above mentioned can create sustainability of the business in the long term.

\section{References}

Aditya, D. A. (2011). Implementasi Corporate Social Responsibility (Csr) Terhadap Perusahaan (Studi Di PT Sidomuncul Semarang). Universitas Negeri Semarang, Semarang. 
Auletta, N., DeWitt, R.-L., Parada, M. J., Sharma, P., and Yusof, M. (2014). The Global Step Booklet Volume II.

Bakoğlu, R., and Yıldırım, O. B. A. (2016). The Role of Sustainability in Long Term Survival of Family Business: Henokiens Revisited. In 12th International Strategic Management Conference (ISMC) (Vol. 235, pp. 788-796). Antalya: Elsevier https://doi.org/10.1016/j.sbspro.2016.11.081

Campopiano, G. (2012). Corporate Social Responsibility and Family Business: Different Perspectives to Explore an Under Investigated Topic. The University of Bergamo.

Cho, N. M., Okuboyejo, S., and Dickson, N. (2017). Factors Affecting the Sustainability of Family Businesses in Cameroon: An Empirical Study in the Northwest and Southwest Regions of Cameroon. Journal of Entrepreneurship Journal of Entrepreneurship: Research and Practice, 2017. https://doi.org/10.5171/2017.658737

Dobson, J. R., and Swift, J. S. (2008). The Sustainability of Family Businesses: Evidence from Three UK Case Studies. Journal of Business Management, $1,57-72$.

Hadi, A. C. (2016). Corporate Social Responsibility Dan Zakat Perusahaan Dalam Perspektif Hukum Ekonomi Islam. Jurnal Ilmu Syariah, 16(2), 229-240.

Handjaja, G. (2013). Analisis Penerapan Corporate Social Responsibility di Perusahaan Multilevel Marketing PT. Harmoni Dinamik Indonesia. Calyptra, 2(2), 1-17.

International Organization for Standarization. (2010). Social ResponsibilityDiscovering ISO 26000.

KPMG, and Family Business Australia. (2013). Performers: resilient, adaptable, sustainable. Adelaide.

Kumar, S. and Prameswari, Q. (2018). The Determinants of a Successful Family Business Succession in Indonesia: A Mulitple Case Study. International Journal of Family Business Practices, Vol 1, No. 2, pp. 1-17.

Lee, M. H., Mak, A. K., and Pang, A. (2012). Bridging the Gap: An Exploratory Study of Corporate Social Responsibility among SMEs in Singapore. Journal of Public Relations Research, 24(4), 299-317. https://doi.org/10.1080/1062726X.2012.689898

Lee, M. P. D. A. (2008). A review of the theories of corporate social responsibility: Its evolutionary path and the road ahead. Int. J. Manag. Rev., 10, 53-73.

Mandl, I. (2008). Overview of Family Business Relevant Issues. Vienna.

Mentari, R. A. (2013). Implementasi Corporate Social Responsibility (CSR) pada Pendidikan. Jurnal Akuntansi UNESA, 2(1), 1-24.

Prayudi. (2012). Analisis CSR sebagai Implementasi Praktek Etika Bisnis Perusahaan: Antara Kewajiban dan Kebutuhan. In Bisnis dan Isu-isu Global (pp. 1-17). Yogyakarta: UPN Veteran.

Safi'i, F. A. N. (2014). Studi Kasus Suksesi Bisnis Keluarga Pada Perusahaan Perlengkapan ABRI CV. Universitas Negeri Malang.

Sari, W. D. N. (2014). Penerapan Corporate Social Responsibility Terhadap Masyarakat Di Lingkungan Sekitar Perusahaan: Studi Kualitatif. Jurnal Ilmu and Riset Akuntansi, 3(1), 1-18.

Setyaningrum, D. A. (2011). Pengaruh Implementasi Corporate Social Responsibility Terhadap Kesejahteraan Hidup Masyarakat (Studi Kasus pada PT . APAC INTI CORPORA, Bawen). Universitas Diponegoro. 
Uhlaner, L. M., Goor-Balk, H. J. M. (Annemieke), and Masurel, E. (2004). Family business and corporate social responsibility in a sample of Dutch firms. Journal of Small Business and Enterprise Development, 11(2), 186-194. https://doi.org/10.1108/14626000410537128

Widowati, A. I., Surjawati, S., Oktoriza, L. A., and TL, D. I. (2017). Praktik Islamic Corporate Social Responsibility Disclosure (Studi Kasus Terhadap Perusahaan Yang Terdaftar di Jakarta Islamic Indeks). Jurnal Dinamika Sosial Budaya, 18(2), 207-213.

World Business Council of Sustainable Development. (1998). WBCSD-Corporate Social Responsibility. WBCSD-Corporate Social Responsibility.

Yulita, R. (2018). Menguak Problematika CSR di Indonesia. Retrieved from http://ksm.ui.ac.id/menguak-problematika-csr-di-indonesia/

\section{Additional}

The reason behind the Government of Indonesia's emphasis on MSMEs is creating productive workers, improve productivity and efficiency in technology, and more flexible than the big industry when adjusting with the ever-changing economic condition (Bellefleur, Murad, and Tangkau, 2012).

In Indonesia's case, most successful entrepreneurs come from a family business background. Besides, a family business is most of Indonesia's form of Small and Medium Enterprises (SME) (Rachmania, Rakhmaniar, and Setyaningsih, 2012). In their study, found that Indonesia entrepreneurs are motivated by high income, personal and family life flexibility, have downtime, and family security. For expanding their business, most Indonesia entrepreneurs prefer development on distribution channels, add new products or services, and expanding to a new market.

A study done by (McMorrow and St-Jean, 2013) found that having a fast-growing economy, large market, as well as abundant natural resources available, could generate strong opportunities for entrepreneurs. Hence, based on five pillars of entrepreneurship measurement made by EY G20 Entrepreneurship Barometer 2013 found that Indonesia still has challenges. Poor education level and low spending on RandD create difficulties in creating a more mature entrepreneurial venture. Further, Indonesia ranks poorly for entrepreneurial training also lacks international experience whereby international knowledge networks could be beneficial to business operations and future growth (Asia Pacific Foundation of Canada, 2018).

Data in Table 1 below shows the numbers of MSMEs and employment in the MSMEs in Indonesia.

Table 1: MSMEs data of 2016 and 2017 of Indonesia

\begin{tabular}{|l|l|l|l|}
\hline Indicators & 2016 & 2017 & $\begin{array}{l}\text { Growth } \\
(\%)\end{array}$ \\
\hline MSMES (units) & $61,651,177$ & $62,922,617$ & 2.06 \\
\hline Employment (people) & $112,828,610$ & $116,673,416$ & 3.41 \\
\hline
\end{tabular}

Source: (Ministry of Cooperatives and SMEs of Indonesia, 2017) 
Figure 1: Statistics of SMEs in Bogor City

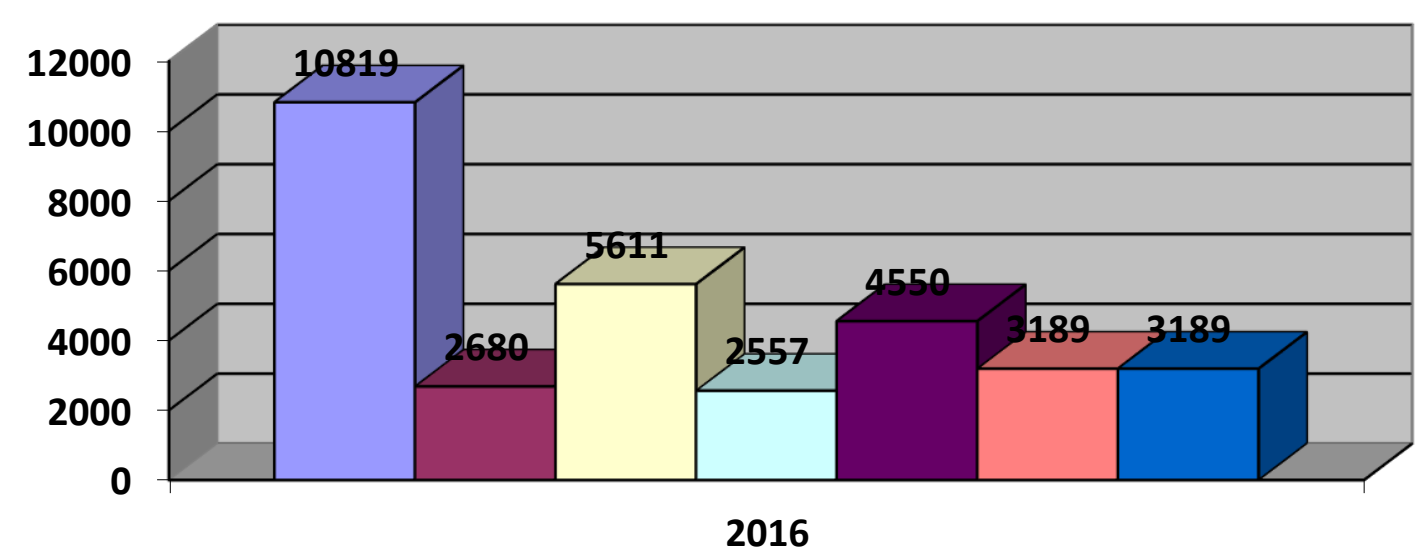

\begin{tabular}{|llll}
\hline$\square$ West Bogor & $\square$ East Bogor & $\square$ South Bogor & $\square$ North Bogor \\
$\square$ Central Bogor & $\square$ Tanah Saral & $\square$ Tanah Saral &
\end{tabular}

Source: (Department of Cooperatives and SMEs of Bogor City, 2019) 